\title{
II. Meşrutiyet Döneminde Siyasal İktidarın Toplumsal Muhalefete Bakış Açısı: Hasan Fehmi Bey Suikastı ve Muhalefetin Tasfiyesi Ismail SAFI ${ }^{1}$
}

\begin{abstract}
Öz
Osmanlı Devleti'nde modernleşme sürecinin başlamasında etkili olan önemli kesim basın mensupları olmuştur. Yeni Osmanlı düşünürleri demokratik sistemlerin temel yapıtaşlarını basın aracılığı ile ilk kuranlar olmuşlardır. Basın mensupları böylece siyasal sistemin işleyişinde, siyasal iktidar üzerinde denetleme görevini üstlenmek gibi bir görev edinmişlerdir. Bu bir demokratik gelenek haline gelmiş ve hep devam ettirilmek istenmiş; fakat siyasal iktidarlar tarafinda bu durum pek de hoş karşılanmamıştır. Siyasal iktidarı elinde bulunduranlar, istikrarı sağlamak bağlamında, sadece basın mensuplarını değil kendilerine karşı açı muhalif tavır sergileyen bütün kesimleri hedef almışlar, öncelikli yasal yollardan sindirip yok etmeye, daha sonra da yasal olmayan yol ve yöntemlerle (komitacı eylemlerle) bu kesimleri sindirmişler ya da yok etmişlerdir. Siyasal iktidarın basın mensuplarına karşı uyguladığı illegal tasfiye sürecinin, başka bir ifadeyle komitacı eylemlerinin başlangıcı, II. Meşrutiyetin hemen sonrasında gerçekleşen Hasan Fehmi Bey suikastıdır.

Hasan Fehmi Bey, II. Meşrutiyet'in ilanıyla birlikte muhalif yazarlar kitlesinden olan ve dönemin siyasal iktidarına ağır eleştirilerde bulunan bir gazetecidir. Suikastı önemli kılan ise Meşrutiyet döneminde öldürülen ilk gazeteci olması, katillerinin bulunamaması ve bu suikastın dönemin en büyük kanlı ayaklanmalarından biri olan 31 Mart Vakıası'nı tetikleyen neden olmasıdır. Ayrıca öldürülmesi muhalefetin sindirilmesine yönelik büyük bir gösterge olması nedeniyle de çalışmanın konusu olmuştur. Çünkü basın, özgürlük ile demokrasinin teminatı ve kamuoyunun sesidir. Çalışmanın amacı II. Meşrutiyetin beklentisini, dönemin iktidar muhalefet ilişkileri yönünden yarattığı koşulu ve bu dönemde muhalefetin tasfiyesinin varlığını ortaya koymaktır. Özellikle suikastı aydınlatmaya ilişkin kaynakların var olmaması çalışmanın kısıııdır.
\end{abstract}

Anahtar Kelimeler: Hasan Fehmi Bey, 31 Mart Vakıası, II. Meşrutiyet, Komitacılık, Siyasal suikast.

Point Of View Of The Political Authority Towards Social Oppositions In The Second Constitutional Era: Assasination Of Hasan Fehmi And Elimination Of Opposition

\begin{abstract}
The members of the press were an effective class of the Ottoman Empire's modernization process. Thinkers of new ottomans were the ones founded the basics of democratic systems through press. Thus, assume the mission for the operation of the political system and checking the political authority. This became a democratic tradition and wanted to be continued. But this wasn't welcomed by political authority. Holders of the political power targeted all opposition groups including to press for the sake of stability. Initially, they tried to eliminate the opposition through legal means, then they used illegal methods to suppress and eliminate opposition. Illegal elimination process implemented by political authority, in other works, initiation of illegal elimination occurred by Hasan Fehmi assassination after the start of second constitutional era.

Hasan Fehmi Bey was a journalist among opposition columnist and heavily criticized the political authority of the era. The significance of the assassination is that he is the first journalist who was killed, killers will never found and this assassination triggered one of the bloodiest insurgence: 31 March incident. The assassination constitute an important indicator of eliminating opposition, so became the topic of the study. Because, public voices is the guaranty for freedom and democracy. The purpose of the study is to clarify condition of authority and opposition relations within in the light of expectation of the second constitutional era and to demonstrate the elimination of opposition. Limitation of the study is the lack of sources regarding to the assassination of Hasan Femi.
\end{abstract}

Key Words: Hasan Fehmi Bey, 31 March Incident, Second Constitutional Era, Komitadji (Comitadjis), Political Assassinations.

${ }^{1}$ Dr. Öğr. Üyesi, İstinye Üniversitesi, İktisadi, İdari ve Sosyal Bilimler Fakültesi, Siyaset Bilimi ve Kamu Yönetimi Bölümü, ismailsafi99@gmail.com 


\section{Giriş}

III. Selim döneminde askeri alanda başlatılan batıl1laşmalmodernleşme hareketi kısa sürede diğer alanlara da sıçramış, Batılı anlamda bir devlet olma yolunda idari reformların yapılmasına sebep olmuştur. Askeri alanda başlatılan modernleşme çabaları, zamanla bir aydın hareketi doğurmuş, böylece Yeni Osmanlı düşünürleri denilen aydın kesimi ortaya çıkmıştır. 1876 itibariyle bu hareketin, devleti ve yönetimi dönüştürme çabaları sonuç vermiş Meşrutiyete geçilmiş ve kesintiye uğramasına rağmen 1908'de II. Meşrutiyet ile nihai sonuç alınmıştır. İşte 1876'da başlayan Türk modernleşmesi Türkiye Cumhuriyeti'nin demokratikleşme sürecinin de başlangıcıdır. Bu tarihten itibaren demokrasinin vazgeçilmez unsurlarının tek tek inşa edildiğini görmekteyiz.

II. Meşrutiyet dönemi ile başlayan demokratikleşme sürecinde siyasal iktidar muhalefet ilişkileri üzerinde fazlaca durulması gereken bir konudur. Başka bir ifadeyle siyasal iktidar ve onu denetleyen kesimler meselesi derinlemesine incelenmesi gereken bir mevzudur. Yeni oluşturulan değerlerden hareketle siyasal sistemin çoğulcu, katılımcı, katılıma firsat tanıyan ve istikrarlı olması hedeflenmiştir. Bunun için siyasal iktidar-muhalefet ilişkilerinin sağlklı olması ve hoşgörülü olması beklenmiştir. Çünkü siyasal iktidarların değişebilirliği ve muhalif unsurlara karşı hoşgörülü yaklaşımı demokratik sistemleri istikrarlı kılan etkenlerdir. Aynı hoşgörülülük kuralı muhalefet için de geçerlidir. Her siyasal muhalefet hareketi bir gün siyasal karar alama mekanizmasında yer alabileceğini bilerek ona göre hareket tarzını oluşturmalıdır. Teoride karşımıza çıkan bu denetleme görevi "muhalefet/muhalif" olarak adlandırdığımız kesimleri ve "siyasal muhalefet" kavramını çıkarmaktadır.

Muhalefet kavramını, "Bir görüşe, tutum ve davranışa karşsı olma durumu, aykırılık; karşı görüşte, tutumda insanlar topluluğu" şeklinde tanımlarken, muhalefet edenleri de "muhalif" kelimesiyle tanımlayabiliriz (Türkçe Sözlük, 1995: 1039). Siyasal muhalefet kavramını ise muhalefet kavramının siyasal perspektif içinde ele alınması ile tanımlamak mümkündür. Başka bir ifadeyle muhalefete ya da muhaliflerin söylemlerine konu olan meselelerin toplumsal ve ekonomik yapıyı, siyasal rejimi ve onun somut öğelerini içine alması ya da bunlara yönelmesi söz konusudur. Buradan hareketle N. Turgut siyasal muhalefet kavramını şöyle tanımlamaktadır: "Belli bir toplumsal biçimlenimde, herhangi bir zaman sürecinde, var olan bir siyasal rejime ve içerisinde yaşanan sosyoekonomik düzene veya bunlardan yalnızca birine ya da siyasal iktidarı elinde bulunduranlara ve/veya bunların faaliyetlerine karşı olmayl, bunları, karşılı̆̆ında alternatif bir program ya da öneri sunarak veya sunmayarak, yasal sınırlar içinde ya da yasal sayılmayan çeşitli yollara başvurarak eleştirmeyi ve bu arada istenilen amaç doğrultusunda etki ve sonuçlar yaratmayı içeren bir olgu, bir davranıştır." (Turgut, 1984: 8).

Siyasal muhalefet parlamento içinde olabileceği gibi parlamento dışında da olabilir. Parlamento dışı muhalefet, parlamento dışında bırakılan kesimlerin karar alma mekanizmasına, 
demokratik kurallar çerçevesinde müdahale etme, denetleme mücadelelerini ve bu durumun da siyasal iktidar tarafindan doğal bir şekilde karşılandığı muhalefet türüdür. Parlamento dışı muhalif kesimlerin belki de en önemlisini basın oluşturmaktadır. Siyasal iktidar- basın ilişkileri bağlamında her toplumda ve her dönemde bir takım sorunlar yaşanmış; iktidar bu denetimden kaçmaya, kendini denetletmemeye çalışırken, basın da kendisini dördüncü güç olarak kendini kabul ettirmeye ve daha fazla denetlemeye çalışmış, böylece de daha fazla sorun yaşanmasına neden olmuştur.

Siyasal iktidarı elinde bulunduranların iktidarlarının idamesi ve meşruiyetlerini sağlamak için kamuoyunun desteğine ihtiyaç duymaktadırlar. Siyasal iktidar sahipleri için aslında kamuoyu desteği yaşamsal niteliktedir. Kamuoyunun oluşmasındaki en önemli etkenin ve kamuoyu sözcülerinin basın olduğunu göz önünde bulundurulursa siyasal iktidar sahiplerinin basınla iyi ilişkiler kurması, muhalif basına karşı hoşgörülü olması gerektiği sonucuna ulaşabiliriz. Fakat teorinin aksine uygulamada pek çok ülke siyasal kültüründe parlamento dışı muhalefetin önemli unsuru olan basına karşı, özellikle de muhalif basına karşı, olumlu bir tutum yoktur; hatta tahammülsüz bir durum söz konusudur ve çoğu zaman bunların faaliyetleri demokrasiden sapma, bir tür normal olmayan muhalefet türü olarak değerlendirilmiştir. $\mathrm{Bu}$ durum işte Osmanlı Devleti hatta daha sonra onun mirasını alan Türkiye Cumhuriyeti için de geçerlidir.

Basın siyasal iktidar arasındaki bu durum diğer muhalif unsurlar için de geçerlidir. Gerek Osmanlı Devleti gerekse sonrasında kurulan Türkiye Cumhuriyeti için olsun Türk siyasal kültüründe muhalefete karşı özellikle de parlamento dışı muhalefete karşı oldukça tahammülsüz bir tutum olduğunu görmekteyiz (Mardin, 1991: 181-182). Üstelik bu durum yani siyasal iktidarın muhalefete karşı sert ve katı tutumu devamlılık göstermektedir. Muhalif unsurların ve muhalefetin ilk defa ortaya çıkmaya başladığı Osmanlı Devleti'nin son dönemlerinden yani II. Meşrutiyet'ten itibaren 1960'lı yıllara kadar, siyasal iktidarın tahammülsüzlük içeren bu tutumunun süreklilik taşıdığını gösteren deliller Şerif Mardin tarafından ortaya koyulmuştur (Mardin, 1991: 182). Mardin'in de üzerinde durduğu gibi bu tahammülsüz tutumun en fazla yoğunlaştı̆̆ parlamento dişı muhalif kesim ise gazetecilerdir. Sonuç olarak siyasal iktidarlar her türlü muhalif tutumu düşmanca bir öğe gibi algılamış ve bulduğu ilk firsatta hep muhalefetin tasfiyesine başvurmuştur. Toplumsal muhalefete karşı tasfiye hareketinin başlangıcı ise Gazeteci Hasan Fehmi Bey suikastıdır. Bu suikast siyasal yaşamda derin etkiler bırakan bir olaydır. Bu suikastın ardından İttihat ve Terakki Cemiyeti'nin fırkaya dönüşmesine ve Meşrutiyet'in olmazsa olmazları arasında bulunan "muhalefet" partilerinin siyasette varlık gösterememelerine sebep olmuştur. Başka bir ifade ile büyük umutlarla ilân edilen II. Meşrutiyet'in daha başında böyle bir olayla karşılaşması, Meşrutiyet'e duyulan güveni sarsmıştır (Kurşun, 2000: 44).

Hasan Fehmi Bey suikastı ile ilgili literatürdeki çalışmalar (Ayaz vd. 2015; Ahmad, 2016; Akşin, 2014) ve muhalefete ilişkin olarak birtakım içerikleri (Savaş, 1998; Akbal, 2004 Kerimoğlu, 2007; Kerimoğlu, 2009; Aslan, 2009; Akbal ve Akınc1, 2013); kapsamaktayken muhalefetin tasfiyesini anlatan çalışmalar çok fazla mevcut değildir. Çalışma bu alandaki bir eksikliği giderme 
hedefini üstlenmektedir. Ayrıca çalışma, suikastlara varan bir muhalefete karşı tahammülsüzlügü ve bu durumun halk tarafından ayaklanmaya yaklaşılması (31 Mart Vakıası) noktasında önemli bir problem alanına yoğunlaşmakta ve bu haliyle daha önemli hale gelmektedir.

$\mathrm{Bu}$ çalışma, literatür tarama ile elde edilen ikincil kaynakların yanı sıra hatırat ve Osmanlı basını üzerinden elde edilen birincil kaynaklar üzerinden hazırlanmıştır. Çalışmada II. Meşrutiyet süreci ve sonrasında iktidar-muhalefet yapısı irdelenerek muhalefetin tasfiyesine ilişkin yapılan Hasan Fehmi suikastı ve akabinde halk muhalefetine ilişkin 31 Mart Vakıası neticesinde muhalefetin tasfiyesini inceleme alanına almış ve süreç değerlendirilmiştir.

\section{Meşrutiyet'in İlanı ve Siyasal Ortam}

II. Abdülhamit'in istibdat yönetimi ve sansür politikası dönemin genç nesli arasında olumsuz etki doğurmuş, fakat Yeni Osmanlılar olarak adlandırdığımız aydın kesimi hiçbir şekilde anayasacılık ve hürriyetçilik hareketinden vazgeçmemişlerdir. Meşruti yönetime erişmek için İbrahim Temo, İshak Sükuti, Abdullah Cevdet, Mehmet Reşit ve Hüseyinzâde Ali isimli genç tıp öğrencileri gizli "İttihad-1 Osmani Cemiyeti”ni 1889'da kurmuşlardır. Daha sonra örgüt üyeleri dönemin diğer mektepleri ve tekke mensuplarını da içine alarak örgütsel olarak büyümüşlerdir. Örgüt faaliyetleri Avrupalı devletlerinin gözü önünde olan Makedonya eyaletinin merkezi olan Selanik’te daha çok göze çarpıyorlardı. Çünkü meşruti hareketin gelişmesi için uygun ortam burada vardı; hafiye teşkilatının ajanlarından uzak, denetimin az olduğu böyle bir ortamda toplantılar rahat yapılabiliyor ve gazeteler okunabiliyordu. $1895^{\prime}$ 'e kadar gizli toplantılar devam etti ve Cemiyetin üye sayısı artt1. Örgüt üyeleri Namık Kemal, Ziya Paşa gibi Genç Osmanlıların eserlerini okuyarak kendilerini yetiştirdiler. Bu süreçte cemiyetin adı İttihat ve Terakki olarak değiştirildi. Cemiyet meşruti yönetimi eski rejim mensuplarına kabul ettirmek için kararlıydı (Metin, 2016: 2-3).

Uzun süren mücadelelerin ardından, İngiltere ve Rusya gibi düvel-i muazzamanın elde kalan son Avrupa topraklarında (Makedonya) "1slahat yapılmadı̆̆ı" gerekçesiyle kaybedileceğini anlaşılınca, Cemiyet basın yoluyla mücadeleye başlamış ve Reval Buluşması'nın ardından silahlı mücadele kararı alınmıştır (Savaş, 1998: 21). Bunun üzerine Makedonya'da İttihat ve Terakki Cemiyeti mensubu subaylar kendilerine bağlı askeri birlikleri alarak dağa çıkmışlar ve isyan neticesinde 1876 tarihli Kanun-1 Esasi yeniden yürürlüğe konularak II. Meşrutiyet ilan edilmiştir. 23 Temmuz 1908 Perşembe sabahı Osmanlı ülkesi üzerinde yaşayan insanlar yeni bir döneme, meşrutiyet dönemine uyanmışlardır (Ahmetoğlu, 2011: 4).

Meşrutiyetin birdenbire ilanı halkı şaşırtmıştı. Basındaki sansürden dolayı Rumeli’deki ayaklanmadan haberi olmayanlar için meşrutiyet padişahın bir hediyesiydi. Meşrutiyetin ardından İkdam gazetesi "Padişahım çok yaşa" diye başlık atıp, olmamış gösterileri yapılmış gibi gösteriyordu. Özellikle halkın mükemmellikleri getireceğini düşündükleri meşrutiyet neticesinde devletin çeşitli yerlerinde barış gösterileri yaşandı. Çeşitli din mensupları ve ırktan insanlar birbirlerini kucakladılar 
(Savaş, 1998: 5). Bu durum neticesinde istibdadın yükü birilerine yüklenmeliydi ve Padişah "Hainler beni şimdiye kadar aldatmışlar" demek suretiyle suçu etrafındaki bürokratlara yıkmıştı. Meşrutiyetin sarhoşluğu halkta büyük çılgınlıklara sebep olmuş, halk meşrutiyetten doğan bu hürriyet ortamında eski rejimden ve onun memurlarından öç almaya başlamıştı. Bunun üzerine halkı yatıştırmak için Padişahın isteği üzerine Şeyhülislam Padişah adına meşrutiyeti koruyacağına dair Kuran'a el basarak yemin etmesiyle halk yatıştırılabilmiştir (Ayaz vd. 2015:108). Bu arada sansür kendiliğinden sona ermiştir. Adi mahkûmların siyasi af istemesi neticesinde genel af çıkartıldı. Yine bu süreçte işçi sınıfı, yaşanan \% 20 enflasyon neticesinde ücret artış talebinde bulunmuş, kabul görmeyince 6 ay içerisinde yüzden fazla grev yapmışlardır (Savaş, 1998: 6-7).

İnsanlar hürriyetin ilanının mucizeler getireceğine inanıyorlardı. Köylüler meşrutiyeti vergi ödememek olarak algılıyor; memurlar ve işçiler ise maaş zammı olarak değerlendiriliyorlardı. Basın özgürlüğün tadını çıkarıyorken ayrılıkçı örgütler meşrutiyeti Osmanlı'dan kopmanın altın anahtarı olarak değerlendiriyorlardı. Çünkü Jön Türkler meşrutiyeti "her derde deva" olarak pazarlamışlar ve böylece kitleleri cemiyete bağlamışlardı (Metin, 2016: 4). Sonuç olarak, beklentiler ve algılamalar farklı olsa da II. Meşrutiyet halkın birçok umuduna cevap aradığı, hürriyetin ve anayasal sistemin teminatı özelliklerini bünyesinde taşıyan demokratik temelli bir sistem olması hasebiyle önemlidir. Meşrutiyet rejiminin umutlara cevap vermesi siyasal iktidar ve muhalefet ilişkilerinin sistemli işlemesine bağlıydı.

Meşrutiyetin ilanıyla birlikte İttihat ve Terakki Cemiyeti siyasal iktidarın rakipsiz siyasi gücü haline gelmişti. Hatta Yıldız’ı geride bırakarak fiili bir iktidar ve başvuru mercii olmuştu (Savaş, 1998: 4). Ancak Cemiyet yöneticilerinin yönetim konusundaki tecrübesizliği ve düzenin bozulması endişesi yönetimi eski rejime (Osmanlı seçkinleri denilen paşalar, üst düzey subay ve sivil memurlara) bırakmak mecburiyetini getirmişti (Metin, 2016: 4). İttihat ve Terakki Cemiyeti perde arkasından yönetimi sürdürse de bu sıralar oluşan yönetim boşluğu nedeniyle birçok dış sorun ortaya çıkmıştı. Bulgaristan bağımsızlığını ilan ederken Avusturya-Macaristan İmparatorluğu Bosna-Hersek’i ilhak etmiş ve Girit ise Yunanistan'a katıldığını ilan etmişti. Yaşanan bu sıkıntılar İttihat ve Terakki Cemiyeti'ne karşı şiddetli bir muhalefetin doğmasına sebep olmuştur (Ahmetoğlu, 2011: 4).

Sait Paşa'ya bırakılan hükümet, Cemiyetin ordu ve hükümet üzerindeki nüfuzunu kırmaya çabalamışsa da başarılı olamamıştır. İttihat ve Terakki Cemiyeti'nin müdahaleleri, ordu içerisindeki alaylı subaylar gibi ikinci plana atılan zümreleri rahatsız etmeye başlamışı. Bu kesimlerin meşrutiyet yönetimi hakkında çıkardığı dedikodular kamuoyunda birtakım tereddütlere yol açmıştı. Cemiyet meşrutiyetle ilgili şüpheleri ortadan kaldırmak için girişimlerde bulunmuş olsa da ortaya çıkan yeni gelişmeler bu girişimi başarısız kılmıştır.

Sait Paşa'nın sadaretten çekilmesiyle iktidarı devralan Kâmil Paşa, Anayasa'da birtakım değişiklikler yapıp hükümdarın hükümete müdahale yetkisini ortadan kaldırdı. Parlamento kanun 
yapma sürecinde de hükümdarın tesirinden kurtulmuş oldu. Kâmil Paşa'nın sadrazamlığının ilk ayında ihtilal zamanlarına has taşkınlıklar devam ediyor; hatta hürriyeti kanuna, nizama uymama, vergi vermeme olarak algıllyorlardı. Vapura, tramvaya para vermeden binmeyi özgürlük sayanlar bile vardı. Kâmil Paşa düzeni tekrar kurmak istiyordu. İktidarında padişah ve gazetelerden destek alamayacağını bildiğinden İttihat ve Terakki Cemiyeti'nin desteğine yöneliyordu. Çünkü siyasal partiler sistemi kurulmamış, normal yolla işleyen iktidar ve muhalefet partisi sistemi mevcut olmadığından Cemiyete muhtaç olduğunu biliyordu. İstanbul'da İttihatçılardan oluşan bir özel kurul oluşturuldu ve Kâmil Paşa ile pazarlıkları bu kurul yerine getirdi (Metin, 2016: 6). Kâmil Paşa durumun sadrazamlık yetki ve sorumluluğuna bir karışma anlamına gelmeyeceğini iddia ediyordu. Kurul üyeleri ise Kâmil Paşa'yı, İttihat ve Terakki Cemiyeti'nin tedbir ve tasarılarını yürütmekle görevli biri olarak görmekte idiler. Sonuçta siyasal iktidarın kullanımı konusunda Cemiyet ile Kâmil Paşa arasında ciddi anlaşmazlıklar vardı. Bu arada ülkedeki siyasal istikrarsızlık ve düzensizlik çözülemedi. İşçi grevleri arttı ve özellikle de ordunun siyasete girmesi büyük sorun oldu (Metin, 2016: 7).

Türk siyasal yaşamının ilk seçimlerinden büyük bir zaferle ayrılmasına rağmen iktidarı doğrudan üstlenmeyen İttihat ve Terakki Cemiyete, kurulan yeni kabineye iki üye vermekle yetindi. Ancak kurulan her kabineye siyasal müsteşarlık yoluyla müdahale etmeye devam ettiler. Ancak bu müdahaleler saray, hükümet ve halk arasında bir mücadelenin başlamasına sebep oldu. İktidar ve otoritenin kimde olduğunu bilen yoktu. Burada hükümetin sorumluluğunu almadan iktidarı elde tutma girişimi söz konusu olduğundan Sait ve Kâmil Paşalar Cemiyeti uzaklaştırma çabalarına giriştiler; fakat başarılı olamadılar (Ayaz vd. 2015: 108-109).

\section{Meşrutiyet Dönemi Siyasal İktidar ve Muhalefet İlişkileri}

Meşrutiyetin ilanıyla birlikte ülkede değişik alanlarda faaliyet yürüten birçok cemiyet kurulmuş, yüzlerce yeni gazete ve dergi çıkarılması mümkün olmuştu. Bu denli çok sayıda demokrasiyi yayma ve yerleştirme aracının kurulmuş olması uzun yıllar istibdat altında yaşayan halkın ülke meselelerini konuşma, düşüncelerini özgürce dile getirme açlığının ve bu açlı̆̆ gidermenin bir gerekçesiydi (Kerimoğlu, 2009: 22). İstibdat dönemi sürgün edilen ve firar eden kişileri çeşitli hak kayıplarına uğratan, onları işlerinden eden ve öğrenimlerini yarıda bırakmalarına sebep olan bir dönemdi. Bu dönemde birçok kişinin mallarına el konulmuştu. Bunun dışında bu dönemin sona ermesi sürgün ve firarilerin devletten aldıkları maaşların da kesilmesine sebep olarak geçim sıkıntısı yaşamalarına sebep olmuştu (Kerimoğlu, 2009: 25). Bu yüzden meşrutiyetin ilk yılları istibdatın yol açtığı sorunları çözmeye çalışılmakla geçti. Özellikle devlet memurlarının ihtiyaç fazlasının işten çıkarılması ve maaşlarda belirli bir düzenlemeye gidilmesi demek olan tenkisat bu sorunlardan önemlileriydi. İstibdat döneminde yeterliliğine bakılmaksızın, sadece saraya bağlılığı baz alınarak işe alınan bu kimseler ve işe gitmeyen birçok iş sahibi maaş alıyordu. Anayasal düzene geçen devlet ise artık belirli ölçütlerde personel almalıydı (Kerimoğlu, 2009: 32). 
Büyük umutlarla ilan edilen II. Meşrutiyet'in getirdiği zihniyet bazı kesimleri rahatsız ediyordu. Hoşnutsuzluk giderek artıyordu. Bu huzursuzlukların çıkmasında, kendisini tüzüğünde mukaddes bir cemiyet olarak nitelendirerek meşrutiyetin tek sahibi olarak gören İttihat ve Terakki Cemiyeti'nin uygulamalarının önemli etkisi olmuştur. Doğrudan hükümet olacak deneyim ve birikimleri yoktu; ama hükümetin işlerine müdahale ediyorlardı. Hükümete yapılan müdahaleler gazeteler tarafından "hükümet içinde hükümet" ithamıyla olumsuz değerlendiriliyordu. Hükümetlerin sürekli yenilenmesi huzursuzluk yaratıyordu. Ayrıca Cemiyetin devlet kademelerine kendi adamlarını yerleştirerek kadrolaşmaya çalışması, dini meselelere karşı takınılan lakayt tavırlar, herkesi ittihatçı olmak için zorlayan fiiller, ittihatçı olmayanların vatan haini gibi görülmesi, cemiyete girdiğini ispat etmek için yemin etmeyenlerin tutuklanması, farklı siyasi oluşumlara hayat hakkı verilmemesi noktasında tekelcilik, aşırı siyasallaşma ve özellikle de basının etkisi meşrutiyet ortamının düzeninin bozulmasında etkili olmuştu. Cemiyetin kendilerini eleştiren gazetelere baskı uygulaması ve hatta gazete sahiplerini dahi baskı altına almış olması söz konusuydu.

Meşrutiyet ve Cemiyet aleyhine fiilde bulunanlar çeşitli cezalara çarptırılıyorlardı. Cemiyetin denetiminden uzakta olan yerler de meşrutiyet aleyhtarlığı söz konusuydu. Cemiyet çözümü bu bölgelere heyetler göndermekte buldu. Meşrutiyet karşıtı görüş ileri sürenler tasfiye edildiği için aralarında husumet olanlar asılsız ihbarlarda bulunarak toplumda güveni sarsıyorlardı. Selanik, Manastır ve Kosova'da çıkartılan genel af ilanı neticesinde halk saraya yürümüş kendi yakınlarının da aftan yararlandırılmasını; hatta kimi nazırların, subayların, valilerin ve memurların işten atılmasını istemişlerdi. Bir düzensizlik vardı ve düzensizliğin sebebi de Cemiyet olarak değerlendiriliyordu (Metin, 2016: 5). Hakları iade edilmediği için sürgün ve firariler de muhalefet saflarına geçmişlerdi. Çünkü bu kimseler istibdat döneminde iken maaş alıp karınlarını doyuruyorlardı; Meşrutiyetle birlikte aç kalmışlardı.

Meşrutiyetin ilanı üzerine kadınların giriştiği gazete-dergi çıkarma, dernek kurma, tören ve toplantılara katılma gibi faaliyetler bazılarınca çirkin hareketler olarak yorumlandı ve meşrutiyetin örtünmeye son vereceği söylentileri yayılmaya başladı. İttihat ve Terakki Cemiyeti buna karşı bir bildiri yayınladı. Hükümet dine yönelik uydurma söylemleri ortadan kaldırmak adına, bir ilânla Şeriat ve İslâm adabına aykırı gazete yazıları hakkında kanun yoluna gidileceğini ihtar etti. Abdülhamit'in hafiye teşkilatının kaldırılması binlerce nitelikli kişinin geçimini zorlaştırmıştı. İşçi grevleri baş göstermişti. Bir de dıştan gelen Bulgaristan'ın bağımsızlığı gibi olaylar daha üçüncü ayını doldurmayan meşrutiyetin itibarını yerle bir etmişti. İttihat ve Terakki Cemiyeti'nin Türkçü ve merkeziyetçi yapısına karşı kurulan ve âdem-i merkeziyetçi bir programa sahip olan Ahrar Fırkası kurulmuştu. Sada-yı Millet, Serbesti, İkdam, Sabah ve Volkan gazeteleri de Ahrar Fırkası'nı destekliyorlardı (Savaş, 1998: 8-10).

Cemiyete yeni alınan üyeler ki bunların içerisinde eski devrin adamlarının olması, içeride küskünler grubunun oluşmasına neden olmuştu. Çünkü bu kimseler firari ve sürgünler kadar 
Meşrutiyete katkı sağlamamışlardı. Bunlar aracılığıyla Cemiyet aleyhinde bir takım olumsuz bilgiler (yolsuzluk ve rüşvet haberleri) muhalif gazetecilere aktarılıyordu ve onlar da yayınlıyorlardı. Bunlar arasında İkdam'da Ali Kemal, Serbesti'de Hasan Fehmi ve Mevlanzâde Rifat, Mizan'da Murat Bey, Volkan'da Derviş Vahdeti İttihat ve Terakki Cemiyeti'ni en sert şekilde eleştiren muhalif gazeteciler olmuşlardı (Kerimoğlu, 2007: 4-5).

Yolsuzluk ve rüşvet yazılarının yanında muhalif gazeteler, halktan gelen yakınmalara da gazetelerinde yer veriyorlardı. Dolayısıyla bu talepleri ilgili mercilerin dikkatine sunarak sorunlarının çözümüne yardım ediyorlardı. Bu sorunlar içerisinde esnaf kethüdasının yaptığı baskılar, eğitimsiz polislerce yapılan yasa dışı davranışlar, tarihi eser yağmalarına müsaade edilmesi, aşar vergisinin toplanmasında Anadolu'nun çeşitli yerlerinde yapılan yolsuzluklar gibi birçok konu bulunmaktaydı (Kerimoğlu, 2009: 30).

Basın, Cemiyet için sert yazılar yazıyordu. Ulema görüntüsündeki kimseler hükümet aleyhine mitingler yapıyordu. "Kör Ali Vakıası” 31 Mart Vakıası'nın provası niteliğinde bir irtica girişimiydi. $\mathrm{Bu}$ kişilerle bağlantısı mevcut bulunan Mizan gazetesi yazarı Murat Bey sürgün edilmiş ve gazetesi kapatılmıştı. Çok zaman geçmeden gerçekleşen Beşiktaş karakolu önünde gerçekleşen linç olayı ile Karagöz olayları ayaklanmaya giden süreçte ciddi muhalif hareketlerdi (Ayaz vd. 2015: 109).

Bulgaristan'ın bağımsızlığı Kâmil Paşa'nın siyasi bir deha olmadığını göstermişti. İttihat ve Terakki Cemiyeti ile aralarında bu tarihten sonra ciddi anlaşmazlıklar yaşanmaya başlandı. Servet-i Fünun, Yeni Gazete, Alemdar gibi muhalif gazetelerin desteğini alan Kâmil Paşa fütursuz davranıyordu. İttihat ve Terakki Cemiyeti ise Kâmil Paşa'yı iktidardan indirmek istiyordu. Cemiyet Kâmil Paşa'ya karşılık Girit silahını kullanıyordu. Cemiyet İstanbul'daki askeri dayanağı olan Avcı Taburları'nı geri göndermeye kalkıştı. Bunun üzerine çıkan çatışmalar neticesinde Kâmil Paşa kabinesi çekildi ve yerine Hilmi Paşa kabinesi kuruldu (Savaş, 1998: 13-14).

Özetlemek gerekirse bu tarihten sonra İttihat ve Terakki Cemiyeti üç tür muhalif unsurla mücadele etmeye başladı. Ahrar Fırkası bunlardan birincisiydi. Sürekli kaybettiği seçimler neticesinde hırslanmış olan bu fırkaya Kamil Paşa da katıldı. Öte yandan ulema ile tarikat şeyhlerinin alt tabakasında olan dini çevrelerdi. Ayrıca Cemiyetin yabancı saldırılarına karşı koyamaması Abdülhamid'i müdahaleye zorluyordu. Son olarak Cemiyetin uğraşması gereken üçüncü kesim ise muhalif gazetecilerdi (Savaş, 1998: 16).

Ordu içerisinde Meşrutiyet öncesi padişahın değer verdiği alaylılar ile Meşrutiyetin önemli askerleri olan mektepliler arasında çatışmalar yaşandı. Volkan gazetesinin mağdur olduğunu söylediği alaylı askerlerden gelen mektupları yayınlaması çatışmanın canlı kalmasına sebebiyet verdi. Derviş Vahdeti, gazetesi Volkan'da yazdığı yazılarda hem yandaşlarını etkiliyor hem de Cemiyeti eleştiriyordu. Dinin elden gittiği propagandasını yapıyordu. Avrupa meraklısı bu kimselerle savaşmak gerektiğini, şeriat dışında hürriyet olmadığını yazıyordu. Ayrıca kurucusu olduğu İttihad-1 
Muhammedi Cemiyeti üyeleri ile birlikte askerden İttihat ve Terakki Cemiyeti’ne haddini bildirmesini istiyordu. Aynı şekilde Mizan gazetesi de dini duyguları ayaklandıran yazılar yazıyordu. Volkan ve Serbesti Cemiyete en sert eleştirileri yapan gazetelerdi. Özellikle Serbesti'nin editörü ve başmuharriri Hasan Fehmi Bey, Cemiyetin işlediği yolsuzluklar üzerine belgeler yayınlıyordu. İkdam gazetesi işlerin kötüye gittiğini yazıyor ve Cemiyetin varlığını sorguluyordu (Ayaz vd. 2015: 110-111).

Kısaca özetlemek gerekirse, siyasal iktidar-muhalefet ilişkileri bağlamında baktığımızda, 1909 yılı Mart ayı sonuna doğru siyasal hava çok gerilmiş ve yeni siyasal rejimin geleceği tehlike altına girmişti. İktidar partisi olan İttihat ve Terakki iç ve dış sorunlar karşısında köşeye sıkıştırılmış ve çözümü otoriter bir giysiye bürünmekle bulmuştu. İstibdatın otuz yıllık eziyeti bitti diyenler yanılmışlar, yeni ve sert bir yönetimle karşılaşmışlar ve buna karşı ciddi bir muhalefet ortaya çıkmıştı (Aysal, 2006: 23).

\section{Hasan Fehmi Bey Suikastı, 31 Mart Vakıası ve Muhalefetin Tasfiyesi}

II. Meşrutiyetin ilanı sonrası siyasal iktidar tarafindan yürütülen faaliyetler bir zamana kadar takdir görse de belirli bir aşamadan sonra tavırların eleştirilmeye başlandığını görmekteyiz. $\mathrm{Bu}$ eleştirilerin İttihat ve Terakki Cemiyeti'ni rahatsız etmesi neticesi olarak bir takım baskı içerikli adımlar atıldığı ve de suikastlar işlendiği görülmektedir. Başka bir ifadeyle İttihat ve Terakki Cemiyeti siyasal iktidarı elde ettikten sonra, onu korumak ve devam ettirmek için, iktidarın önünde açık ya da gizli muhalif tavır sergileyen bütün kesimleri hedef alarak komitacı yöntemlerle susturmuştur. Komitacıllk olarak siyasal literatüre yerleşen bu kötü devlet geleneği sayesinde Cemiyet adeta devlet içinde devlet olmuş, muhalif kesimleri tedhiş ve korku siyasetiyle susturmuştur. Öncelikli olarak yasal yollardan muhalefeti temizlemek ve tasfiye etmek istemi, başaramadiysa illegal yöntemlere başvurmuştur. İllegal yöntemler arasında en bilineni de siyasal suikastlardır. Bunlar arasında en fazla mağdur olan kesimler ise parlamento mensupları, aydınlar ve basın mensupları olmuştur. İlk zamanlar II. Abdülhamit'in gizli hafiyelerine düzenlenen suikastlar zamanla daha geniş bir kitleye yöneltilmiş, Paşaları hedef almış ve en sonunda da gazeteciler öldürülmüştür. İttihat ve Terakki komitacılarının her yıl işledikleri gazeteci suikastları bunlardan en meşhurlarıdır. Gazeteci suikastlarının başlangıcı da Hasan Fehmi Bey suikastıdır.

\section{Hasan Fehmi Bey Suikastı}

Hasan Fehmi Bey, 1874 yılında, Teselya/Yenişehir'de aristokrat bir Arnavut ailenin çocuğu olarak dünyaya geldi. Mülkiye Mektebi'nde eğitim almıştır. Mülkiye’yi bitirince istibdatta karşı duruşundan dolayı Mısır'a sürgün gönderilmiştir. Orada Mahmut Paşa'nın himayesinde Emel Dergisi'ni çıkarmıştır. Oradan Paris'e geçmiş ve İttihat ve Terakki Cemiyeti ile tanışmıştır. Prens Sabahattin ile tanışıklığı buradandır. Muhtemeldir ki liberal görüşlerini de Prens Sabahattin'den edinmiştir. Cemiyetin çıkardığı Meşveret'te yazılar yazmış ve II. Meşrutiyetin ilanıyla birlikte İstanbul'a dönmüştür (Tanin, 26 Mart 1325, 1). İstanbul'da Mevlanzâde Rıfat'nn sahibi olduğu 
Serbesti Gazetesi'nde editörlük ve başyazarlık görevi ile gazetecilik mesleğine başlamıştır (Milliyet, 21.1.1955, 7). Her ne kadar İttihat ve Terakki ile birlikte çalışmak istese de radikal görüşlerinden dolayı dışlanmıştır. Böylece radikal ve muhalif yazarlardan biri olarak gazetecilik görevini sürdürmüştür (Ayaz vd. 2015: 11; Çaycı, 2009: 30).

Hasan Fehmi Bey, hürriyetin ilanından sonra diğer küskün ittihatçılar gibi Fedakarân-1 Millet Cemiyeti'ne üye olmuştur (Kerimoğlu, 2007: 6). Daha sonra da muhalefetin toplanma noktası olan Ahrar Fırkası'na katılmıştır. Fırkanın manevi başkanı Prens Sabahattin idi ve fırkanın programı Prens Sabahattin'in görüşlerini ihtiva ediyordu. Bu yüzden Ahrar Fırkası geniş bir âdem-i merkeziyet anlayışını savunuyordu. Bu anlayış Hasan Fehmi’yi firkaya yaklaştırmıştır. Gazetesinde âdem-i merkeziyetçi anlayışı savunmaya başladı ve gerçek anlamda bir muhalefetin oluşması için çaba sarf etti. $\mathrm{Bu}$ arada Cemiyetin vaatleriyle uygulamalarının farklı olduğunu görünce toplumsal muhalefet rolünü de üstlendi. Ancak gazetesinde kullandığı dil çok sert olduğu gerekçesiyle hep eleştiriliyordu. Yazılarında kullandığı sert dil halkı galeyana getirecek derecede güçlüydü (Ayaz vd. 2015: 112). Önceleri yazılarından dolayı tehdit edilse de kendisi bunu önemsemedi. Eleştirel yazılarını sürdürdü (Akbal ve Akıncı, 2013: 42). Ama muhalefete karşı tahammülsüzlük eninde sonunda onu buldu.

Gazetesinde 6 Mart'ta yayımladığ memurlarından şantaj yoluyla para aldığını iddia ediyordu. Aradan birkaç gün geçtikten sonra gazete bu kez hürriyet kahramanı Resneli Niyazi’nin Cemiyetten istifa ettiğini yazdı; fakat Resneli Niyazi bu haberi derhal yalanladı (Ahmad, 2016: 70). 6/7 Nisan 1909' $\mathrm{da}^{2}$, yani 31 Mart ayaklanmasından 6/7 gün önce bu siyasi karışıklık ortamında arkadaşı Şakir Beyle Galata Köprüsü üzerinde yürürken saldırıya uğradı ve öldürüldü (Aysal, 2006: 23).

Galata Köprüsü üzerinde yapılan saldırıda Mülkiye Kaymakamı Şakir Bey yaralı olarak kurtuldu (Milliyet, 21.1.1955, 7). Saldırganın ateş etmeden önce "Al Mevlan” diye bağırması Şakir Bey’i gazetenin sahibi Mevlanzâde Rıfat'a benzetildiğini göstermekle birlikte katil ya da katillerin Hasan Fehmi Bey ile ikisini birlikte öldürmek istediği izlemini yaratmaktadır (Çaycı, 2009: 30). Yaralı olarak saldırıdan kurtulan Şakir Bey, polise verdiği ifadede saldırganın yakasında kırmızı işaret bulunan parlak düğmeli kaput giydiğini ve ilk ateşten önce “Al Mevlan!” diye bir ses duyduğunu söylemiştir. İkinci sefer üç el ateş açıldığını ve Hasan Fehmi’nin bu kez öldürüldüğünü ifade etmiştir (Ahenk, 10 Nisan 1909, 2). Şakir Beyin ifadesine göre katilin bir subay olduğu anlaşılmıştır. Bu kanıyı diğer gazeteler de Şakir Beyin karakoldaki ifadesine dayanarak dile getirmişlerdir. Ahenk gazetesinde sayfalarca verilen ifade metnine ve son olarak gazete muharririnin ifadesine göre aslında vurulmak istenenin Mevlanzâde Rıfat ve Hasan Fehmi Bey olduğu, Şakir Beyin Mevlanzâde Rıfat'a benzediği için yanlışlıkla vurulduğu anlaşılmaktadır: "Mecruh Şakir Bey uzun boylu, sakallı ve Mevlanzâde Rıfat Beye benzer imiş. Hatta mecruh Yeniköprü Karakolu'na geldiği sırada “Beni Mevlanzâde Rıfat

26 Nisan tarihi Türkiye Gazeteciler Cemiyeti tarafından “Öldürülen gazeteciler günü” ilan edilmiştir (Milliyet, 21.1.1955, s. 7). 
Beye teşbihe ettiklerinden vurdular. Onları kaç kere o kadar şiddetli yazı yazmayın diye ihtar ettim" demiş ve “onlar bil ki geçenlerde Ferah Tiyatrosu'nda vukua gelen münazaada bağıran zabitlerden olduğundan şüphe ediyorum " ifadeleriyle katilin hüviyeti hakkında beyanı fikir eylemiştir." (Ahenk 10 Nisan 1909, 3).

Tarık Zafer Tunaya da bu iddiaya katılmaktadır. Yani Şakir Bey yanlışlıkla vurulmuştur; ancak Hasan Fehmi Bey hakkında kesin bir kanaat yoktur (Tunaya, 1988: 416). Bilerek mi vuruldu? Yoksa Şakir Bey'i ıskalayan kurşun onun kafasına mı isabet etti? Kesin bir kanıt ve kanaat yoktur. Nihayetinde katil bir türlü bulunamamıştır (Ayaz vd. 2015: 111-112). Ancak gerek Şakir Beyin Ahenk'teki ifadesinde (Ahenk 10 Nisan 1909, 3) gerekse cinayetten bir gün önce Volkan gazetesine gelen 23 Mart 1325 (5 Nisan 1909) tarihli tehditname sureti katilin bir subay olduğuna işaret etmektedir: "Muharrir efendi, Emin olun ki hedef amaline vasıl olmadan karşısına haris-i hakika-i vatan olan bir asker hem de bir elinde pırll pırll parlayan süngüsünü, diğerinde de gümüş gibi nikel mermilerle dolu rovalvörünü hamil kara urbalı bir asker çıkacak, süngüsünü sinende kıracak, kurşununu da beyninde patlatacaktır (imza)” (Volkan, 8 Nisan 1325/21 Nisan 1909, s. 3)

Kamuoyu tarafından cinayet İttihat ve Terakki Cemiyeti'ne ihale edilmiştir. Bu kanaatin oluşmasında elbette birinci faktör basındır (Aysal, 2006: 24). Katilin bir subay olduğu ve Cemiyet tarafından korunduğuna dair söylentiler bütün muhalif gazeteler tarafından sayfalarına taşınmıştır. Örneğin Ahenk'in 8 Nisan tarihli sayısı doğrudan Cemiyetin ismini zikretmiştir: "Fehmi Efendi'nin keyfiyeti katlinde İttihat Fırkası'ndan şüpheleniliyor. Ortalıkta heyecan vardır." (Ahenk, 8 Nisan 1909, 1).

Aynı şekilde muhalif basının güçlü sesi İkdam da 14 Nisan 1909 tarihli yayınladığı bir asker mektubuna dayanarak doğrudan Cemiyeti hedef almaktadır: "Adam öldürüyorlar, katili sakllyorlar... Hani şeriat? Katili niçin meydana çıkarıp idam etmiyorlar? Kur'an bize kısas emretmiyor mu? İște biz bugün şeriat istiyoruz. Şeriatı getirmek için burada bir ay kalmak gerekiyorsa kalacağız." (Yalçın, 2000: 138).

Katilin bir subay olduğu, Cemiyetin katilin bulunması noktasında hiç çaba sarf etmediği, hatta katili sakladığı, bu yüzden katili yakalama konusunda lakayt davrandığı iddiaları her gün dillendiriliyordu. Muhalefet her koldan suçu cemiyete yüklüyordu. Belki de katilin bulunmaması bu iddiayı güçlendiren bir gerekçeydi (Ahmad, 2016: 71). Cinayeti İttihatçıların işlediğine dair bir diğer kanıt da Cemiyetin fedailik yapacak birçok kimseye sahip olduğu idi. Diğer taraftan eski dönemin önde gelen hafiyeleri de öldürülmüştü. Şimdi sıra gazetecilere mi gelmişti?

Tunaya da kamuoyunda İttihatçıların cinayeti işlediğine dair güçlü bir kanı olduğundan bahsetmektedir (Tunaya, 1988: 417). Tunaya "Mevlanzâde Rlfat ve adamı Hasan Fehmi'den kurtulmak isteyen Ittihat ve Terakki Cemiyeti 6 Nisan 1909'da bu kararını uyguladı" demektedir (Tunaya, 1988: 416). Basın tarafından dile getirilen ithamlara Cemiyet doğrudan karşılık vermemiş, 
reddetmemiş olsa da Cemiyetin resmi yayın organı Tanin Gazetesi “Askere iftira edilmesin” başlıklı uzun ve sert bir dille yazılmış makale ile bu söylentileri yalanlamıştır (Tanin, 27 Mart 1325, 2).

Cenaze merasiminin yapıldığı gün, bu siyasal suikast Meclis-i Mebusan'ın gündemine de getirildi. Rıza Nur, Müfit Bey ve daha birçok mebusun imzaladığı önergeyle hükümetten hesap soruldu. Dâhiliye Nazırı'na katillerin niçin yakalanamadığına dair soru önergesi verildi. Gergin bir hava içerisinde sürüp giden görüşmeler sırasında muhalifler ve İttihatçılar birbirlerini suçladılar. Sonunda önerge kabul edildi. Ancak Meclis Başkanı Ahmet Rıza Bey, sorunun cevaplanmasını on gün sonraki oturuma biraktı. Mebuslar itiraz etse de oturum sona erdirildi (Ahenk, 10 Nisan 1909, 3). Zaten dört gün sonra da 31 Mart Vakıası patlak verdi.

Katil ya da katiller bir türlü ele geçirilememiştir. Sonradan Hasan Fehmi Bey’in katilinin bir ara Ankara Valiliği de yapan Abdülkadir olduğu iddia edildi (Aysal, 2006: 24). Bunun yanında katilin, Enver Paşa'nın eniştesi Nâzım Beyi yaralayan Mustafa Necib olduğu görüşünü de ortaya atanlar olmuştur. Ancak öldürenin kimliği kesinlikle belirlenmiş değildir (Kabaçalı, 1993: 97).

\section{Suikast Sonrası Olaylar ve Büyüyen Muhalefet}

8 Nisan günü muhteşem bir cenaze töreni yapıldı. Cenaze kırmızı atlastan yapılmış Türk bayrağına sarıldıktan sonra, tabutun baş tarafina yine kırmızı atlas üzerine "Kefa billahi şehida Muhammed Rasulullah" cümleleri altın tellerle yazıldı. Cenazeye katılanların sayısı elli binin üzerinde idi (Hasan Amca, 2013: 219). Sadi Borak'ın iddiasına göre o günlerde binlerle anılan İstanbul nüfusunu dikkate alırsak elli bin büyük bir rakamdır. Borak'a göre İstanbul'un Atatürk'ün cenaze töreninden sonra gördüğü en büyük cenaze merasimiydi (Borak, 1979: 6). Bu arada cenaze töreni muhaliflerin İttihat ve Terakki Cemiyeti'ne karşı büyük bir gövde gösterisine dönüşmüştü. Çünkü suikast dönemin siyasal iktidarı olan İttihat ve Terakki Cemiyeti’ne mal edilmişti.

Cenaze II. Mahmut Türbesi'ne defnedildikten sonra Mekteb-i Mülkiye-i Şahane'de siyasi tarih hocası Ali Kemal Bey, yaptığı bir konuşmayla öğrencileri galeyana getirmiş, seferber etmiş ve Hukuk Fakültesi ve Mülkiye öğrencileri birleşip Babıâli’nin kapısına gelmişler; Sadrazam Hilmi Paşa'dan katilleri bulmasını talep etmişlerdi ${ }^{3}$ (Hasan Amca, 2013; 215-216). Buradan ayrılan topluluk büyüyerek Sultan Ahmet’te bulunan Meclis-i Mebusan binasına geldiğinde kırk bini aşmıştı (Milliyet, 17.2.1979: 5).

31 Mart Vakıası öncesi bardağı taşıran son damlanın Hasan Fehmi Bey suikast1 olduğu kuşkusuzdur. Dönemin canlı şahitleri ki Pertev Tevfik Bey gibi, Hasan Fehmi’yi öldürenlerin Cemiyet içerisinden birileri olduğuna inanmaktadırlar. Bu hadise üzerine Hasan Fehmi Bey’in yakınlarının ve

\footnotetext{
${ }^{3}$ Sadrazamla görüşmesi için aralarından bir sözcü seçerler ve o sözcü kalabalığın taleplerini Sadrazama iletir. Topluluğun sözcü olarak seçtiği isim Burhan Felek'tir: "Hasan Fehmi'nin katilini isteyen talebe yürüyüşünün başında ve onun sözcüsü olarak yer aldım. Ayrıca cenazesine de katıldım” (Burhan Felek, "Siyasi Olaylar-2" Milliyet, 23.04.1978, s. 16.)
} 
dostlarının öç alma istemi ayaklanmayı (31 Mart) doğuran güçlü sebeplerdendi. Ayrıca cinayetin ertesi günü çıkan gazeteler büyük bir kitleyi harekete geçirmede etkili olmuşlardır.

Hasan Fehmi Bey suikastı muhalif gazeteci cinayetlerinin ilki olması ve komitacı yöntemlerin gazetecilere uygulanmasında daha önce örneği olmaması hasebiyle de önemlidir (Akbal ve Akıncı, 2013: 42). Muhalefet gazeteleri öfkelerini yazılarında ortaya koydular. Serbesti vatanın bu hainlerden kurtarılması gerektiğini ifade ederek İttihatçılara savaş ilan ediyordu. Volkan gazetesi ise orduyu muhalefet saflarına çekme çabası içindeydi (Savaş, 1998: 15-16). Yeni Gazete iki aylık bir mütareke önerisinde bulunuyordu. Mizan ise "Ulemanın Sükûtu" başlıklı ve iri puntoyla yazılmış bir haberle kamuoyunu ve ulema sınıfını göreve çağırıyordu (Akşin, 2014: 200-201).

Suikastta ihmali olduğu tespit edilen zaptiye memurları görevden alınmış; ancak bu durum kimseyi yatıştırmamıştı. Serbesti gazetesi yayınladığı protesto mektubunda İstanbul'un en kalabalık yerinde bu olayın meydana geldiğini söyleyerek gün geçtikçe diğer gazeteler gibi üslubunu sertleştiriyordu. Bu süreçte İkdam, gerçek hürriyetin vatanımıza henüz gelmediğini, Mizan miskinlik içinde bulunan böyle bir hükümete Osmanlı hükümeti denemeyeceğini söylüyor ve Volkan Gazetesi de dini söylemlerle olayı derinleştiren yazılarını halka sunuyordu (Ayaz vd. 2015: 114). Meclisteki muhalif grubun ve basının İttihatçılara bu denli sert saldırılarının yabancı devletlerce çevrilen entrikalarla da alakası vardı. Çünkü batılı büyük devletler Osmanlı Devleti’nden sağladıkları imtiyaz ve işletmelerden mahrum kalmak istemiyorlardı (Aysal, 2006: 17-18).

\section{Mart Vakıası}

Hasan Fehmi Bey'in cenazesi sonrasında siyasal ortamın gerilmesinde ve krizin tırmanmasında Harbiye Nazırı Rıza ve Sadrazam Hüseyin Hilmi Paşa'nın zamanında müdahale etme, gerekli emirleri verme yönündeki kararsızlık ve tereddütleri etkili olmuştu. Herhangi bir tedbir alınmamıştı ve hükümet işin derinleşmesini bir ayaklanmaya dönüşmesini sadece izliyordu. Ayrıca bu konuda Abdülhamit’ten de olayları önlemeye yönelik bir teşebbüs söz konusu olmamıştı.

Muhalefet unsurlarının bu denli faaliyetleriyle iyice gerginleşen ülkedeki siyasal ortam, nihayetinde 31 Mart Vakıası'nın ortaya çıkmasına neden olmuştur (Çavdar, 2011: 70). Hadisenin etken sebebi ve son damlası Hasan Fehmi Bey'in öldürülmesi idi (Felek, 1980: 10). Takvimler Rumi 31 Mart 1325'i (Miladi-13 Nisan 1909) tarihini göstermekteydi. Suikast sonrası gelişen olaylarla birlikte beş gün geride kalmıştı. Taksim civarında bulunan Taşkışla'da IV. Avcı Taburu'ndan Hamdi Çavuş ile diğer çavuş ve onbaşılar yönetimlerindeki askerler ile önce subayları tutukladılar. Ardından diğer kışlaları da ayaklandırdılar. Sabahın dördüne doğru Mebusan Meclisi önüne kadar geldiler ve isyan başlamış oldu (Akşin, 2014: 203).

Bu büyük isyanın Hasan Fehmi Bey suikastı dışında da tabi ki başka birçok sebebi vardı. 31 Mart'ta İstanbul'da yaşanan bu olayın Erzincan ve Erzurum'da da meydana gelmesi söz konusuydu. $\mathrm{Bu}$ durum Volkan Gazetesi sahibi ve Nakşibendi tarikatı mensubu, İngilizci Derviş Vahdeti'nin 
kışkırtmalarıyla olmuştu. Vahdeti'nin Volkan gazetesi Cemiyet mensuplarını "anarşist" olarak göstermiş ve askerle halkı Cemiyete karşı kışkırtmıştır (Volkan, 8 Nisan 1909, 3). Volkan özellikle ayaklanmadan bir gün önce çıkarttığı sayısında doğrudan Cemiyeti hedef göstermiş ve yok etmek için halkı doğrudan ayaklanmaya çağırmıştır: "Ey Osmanlılar, Vatanı ve birbirimizi seviyor muyuz? İspat edelim. Isşte mezalim! İşte istibdat! Meydanda... Bunları def etmek için fikri serbesti lazım değil mi? İşte meşru vaziyet! İşte hürriyet! Bunlarda meydanda" (Volkan, 12 Nisan 1909, 1)

Alman hayranlıkları gözle görülür derecede olan İttihatçıların bu hali İngilizleri de rahatsız etmiş ve isyana destek vermelerini sağlamıştı. Bunun yanı sıra meşrutiyetle birlikte önceden askerlik yapması gerekmeyen medrese öğrencileri de askerlik yapmak zorunda kalmıştı. Bu sebeple askeri kışkırtan diğer grup da bunlardı. Prens Sabahattin'den Mizancı Murad'a kadar ayaklanmaya katkı sağlayan birçok kesim vardı (Metin, 2016: 13-14). Ayrıca meşrutiyetle birlikte işten atılan çok sayıda alaylı subayın kışkırtılması ve de ordu içerisinde siyasete karışmış askerlerin varlığı ayaklanmanın çıkmasında etkili olmuştur (Akşin, 2014: 195-196). Mustafa Turan ve Cevat Rıfat Atilhan ise ayaklanmanın sebebi olarak Siyonistleri birinci derecede sorumlu görmektedirler. Çünkü Yahudiler Filistin'e yerleşmelerini engelleyen II. Abdülhamit'i tahttan indirmek istemektedirler. Bunlardan başka birçok sebep sayılabilir; ancak ayaklanmanın muhalefet tarafından İttihatçılara karşı düzenlenmiş bir darbe olduğu kesindir (Ayaz vd. 2015: 114).

13 Nisan 1909'da başlayan ayaklanma kartopu gibi büyüdü. Ayaklanma "şeriat isteriz" propagandası ile başlamıştı. Daha sonra birçok istek dile getirildi: Şeriatın geri getirilmesi, mektepli subayların komutanlıklardan çekilmeleri ve ordudan tasfiyesi, Sadrazam, Harbiye ve Bahriye Nazırları ile Meclis Başkanının istifası, bazı önde gelen İttihatçı kimselerin İstanbul dışına sürülmesi ve son olarak isyan eden askerlere af çıkarılması istenmekteydi (Ahmetoğlu, 2011: 5). Bu minvalde ayaklanma süresince Adana'da Ermenilerle çatışmalar yaşanmasıyla epey kan döküldü. Karadeniz boğazı açıklarında ise Rus, Basra limanında İngiliz, İskenderun'da Fransız ve Mersin'de ise İtalyan savaş gemileri görüldü (Savaş, 1998: 16).

$\mathrm{Bu}$ arada ayaklanmayı daha vehim bir duruma götüren ise ölenler arasında bakan ve milletvekillerinin olmasıydı. Olaylarda Hüseyin Cahit'e benzediği için Adliye Nazırı Nazım Paşa, Ahmet Rıza ve Lazkiye Mebusu Aslan Bey de öldürülmüştü. Bu arada bir gün önceden uyarılan İttihatçıların hepsi bir yere saklanmışlar ya da Rumeli’ye kaçmışlardı. Olayın büyümesi isyancılara yapılan nasihatleri de boşa çıkardı. Bunun üzerine kabine istifa etti. Tevfik Paşa tarafından yeni kabine kuruldu.

Ayaklanma neticesinde başkent birkaç gün karışık kaldı. Çünkü II. Abdülhamit durumun karışıklığını ve kan dökülmemesini gerekçe göstererek ayaklanma karşısında İstanbul'da bulunan askeri birlikleri kullanamadı (Tabak, 2005: 115-116). Makedonya'nın birçok şehri Kanun-1 Esasi ve meşrutiyetin devamı için isyana karşı tepki gösterdi. Padişah'a, Meclis-i Mebusan'a ve Sadarete 
protesto telgrafları gönderdiler. İsyanı önlemek adına gönüllülerden oluşan bir ordu bile kurulmaya başlandı. Öte yandan isyanın başlaması sonrası halktaki huzursuzluğun önüne geçebilmek için bir muhabere ağı kurularak gelen haberleri belediye önlerinde bekleşen halka sunarak onları teskin etmeye çalışmışlardır. Ayrıca bu haberleri almak için halkın nöbetleşe beklemeleri meşrutiyete verdikleri önemi de göstermektedir.

İttihatçılar isyana hazırlıksız yakalanmıştı. İki günde orduyu zar zor hazırlayabilmişlerdir. 15 Nisan'da hareket ordusu Selanik'ten yola çıktı (Ahmetoğlu, 2011: 5). Hükümet Hareket Ordusu'nun İstanbul'a girmesini istemiyordu. Çünkü gelirse iki ordu arası bir savaş yaşanabilirdi. Bunun için ordu komutanı ile konuşulsa da Hareket Ordusu'nun gelmesine mâni olunamadı (Çavdar, 2011: 76; Ahmad, 2016: 77). Hareket ordusu 23 Nisan 1909'da İstanbul'a ulaştı. 26 Nisan 1909'da İstanbul'da kontrolü sağlamayı başardı. Şehirdeki askeri birlikler hareket ordusuna dahil edilmedi. II. Abdülhamit, ayaklanmada gerekli tedbirleri almadığı ve isyancıları cesaretlendirdiği gerekçesiyle tahttan indirildi. Bunun üzerine Meclisi Mebusan V. Mehmet Reşat'1 27 Nisan 1909'da tahta çıkard. II. Abdülhamit suçsuzluğunu ispatlamak için tahkikat istese de Meclis bunu kabul etmedi. Reşat ise görevi süresince önüne gelen her şeyi imzalayarak hiçbir şahsi girişimde ve inisiyatifte bulunmayan bir yönetim sürdürdü (Tabak, 2005: 115-116).

Hareket Ordusu'nun, on günlük süreçte, isyanın bastırılması ile faaliyetleri sonucu ortaya çıkan tablo pek hoş bir tablo değildi. Ayaklanma sırasında 49 şehit, 82 yaralı verilmiş; asilerden ise 400 civarında kişi ölmüş, 700 civarında kişi de yaralanmıştır. Divan-1 Harp suçlu bulduğu 49 kişiyi idam etmiştir. İdam edilenlerin arasında ayaklanmanın yönlendiricilerinden Volkan Gazetesi sahibi Derviş Vahdeti de bulunmaktaydı. Bu isyanın Hareket Ordusu ile bastırılması İttihatçıların prestijinin artmasına sebep olmuş, ülke genelinde Cemiyetin otoritesini hissettirmesine imkânı vermiştir (Metin, 2016: 15; Çopur, 1982; 144). Artık bu tarihten sonra İttihat ve Terakki Cemiyeti, kabinelerde daha fazla bakanla bulunmaya başlamış ve üç yıl sürecek sıkı yönetim uygulamıştır. Artık muhalefete tahammül etmesi için bir neden de kalmayacaktır.

\section{Muhalefetin Tasfiyesi}

İsyanın bastırıldığını gören ayaklanmacılar İstanbul'dan kaçmaya başladılar. Bunların başında Volkan Gazetesi ve İttihâd-1 Muhammedi Cemiyeti kurucusu olan Derviş Vahdeti, Serbesti Gazetesi Başyazarı Rifat Bey, Kâmil Paşazâde Sait Paşa, Âli Kemal, Abdullah Zühtü, İsmail Kemal, Ergiri Milletvekili Müfit, Ahrar Partisi Genel Sekreteri Nurettin Ferruh Beyler kaçanlar arasındaydı.

Ayaklanmanın bastırılması sonrasında kaçamayan muhalifleri ve genel olarak muhalefeti zor günler bekliyordu. Hâlihazırda isyanı bastırma gücüne erişmiş olan İttihat ve Terakki Cemiyeti sıkıyönetim ilan etti ve bu süreçte hiç kimseye göz açtırmadı. Cemiyete yakın olmayan kimseleri isyancılar olarak kabul ederek tasfiye sürecine girişti. Açık bir ifadeyle bu isyan Cemiyetin öyle işine 
yaramıştır ki muhalif tutumda olan her türlü birey ve kurum isyanla ilişkilendirilerek tasfiye sürecine tabi tutulmuş̧ur.

İlk olarak isyanla ilişkilendirilerek bütün siyasi oluşumlar kapatıldı. Hatta İbrahim Temo ile Abdullah Cevdet'in kurucuları olduğu Osmanlı Demokrat Fırkası gibi 1lımlı muhalefet yapan partiler bile kapatılmasa da gazeteleri kapatıldı (Metin, 2016: 15). Fakat asıl üzerinde durulan ve ayaklanmanın tertipçisi olduğu tahmin edilen parti Ahrar Fırkası idi. Mevlanzâde Rıfat anılarında bu konuda herkesin hem fikir olduğunu söylemektedir: "Velhasıl birinci günü akşama kadar isyan hareketlerinde tam bir düzen görüldü. Bundan dolayl Ahrar Fırkasl tarafindan tertiplendiği söylentileri İstanbul'un her tarafina yaylldı. Ittihat ve Terakki Cemiyeti'nin ortadan kaldirlmasina yönelik bir isyan olduğu söylenir oldu." (Mevlanzâde Rıfat, 2010: 50).

Tekrar aynı sıkıntıyı yaşamak istemeyen İttihat ve Terakki Cemiyeti Ahrar Fırkası'na karşı cephe alarak siyasi muhalifleri sindirme politikasını izledi. Bu süreçte eski nüfuzunu yeniden kazanan İttihat ve Terakki Cemiyeti mecliste arkası arkasına kanunlar çıkardı (Van, 2012: 285-286). İsyan sonrası süreçte İttihat ve Terakki Cemiyeti'nden başka var olan siyasal partiler büyük baskılar altında ve sadece meclis içerisinde varlıklarını devam ettirebildiler (Savaş, 1998:17).

Geniş çapta tutuklamalar yapıldı. Tutukluların ilk soruşturmalarını yapmak üzere tahkik heyetleri (araştırma komisyonları); olaya sebep olanların halk tarafından ihbar edilmesi için tetkikat heyetleri (inceleme komisyonları) ve suçluların yargılanarak cezalandırılması için divan-1 harp (askeri sıkı yönetim mahkemesi) oluşturuldu (Aysal, 2006: 45-46). İsyancıların sıkıönetim mahkemelerince yargılanması neticesinde 37 kişi ömür boyu hapis, 390 kişi hapis, 139 kişi sürgün cezasına çarptırılması yanı sıra (Ayaz vd. 2015: 114-115) 70 kişi idama mahkûm edilmek suretiyle cezalandırılmıştır. İdamlar ise Beyazıt, Ayasofya, Kasımpaşa ve Köprübaşı'nda gerçekleştirilmiştir. Kurulan divan-1 harpler ile ölüm ve hapis cezalar dışında sürgünler de verildi.

Basınla ilişkilere gelince, isyan öncesi gazete yazıları incelenerek gazete sahipleri ve yazarları sorguya çekildi. Bunlardan da idama mahkûm edilenler oldu. Gazetelerden kimisi geçici kimisi kalıcı olarak kapatıldı. Bu arada unutmamak gerekir ki İttihat ve Terakki Cemiyeti neredeyse bütün iktidarı boyunca muhalif hareketlerde bulunan basınla mücadele içerisinde olmuştur (Savaş, 1998: 21). Hareket Ordusu'nun başarısı neticesinde İkdam gazetesinin 2 Mayıs 1909 tarihli, "Yaşasın Ordu" başlıklı makalesi İttihat ve Terakki'ye karşı bir yaranma girişimi olsa da bir işe yaramamıştır. Bu tür tutum ve davranışlar dönemin Türk basınının duruşunun zayıf olduğunu göstermesi bakımından önemli bir göstergedir. Bunu karaktersizlik ve dalkavukluk olarak değerlendirenler de olmuştur (Aysal, 2006: 49). Serbesti gazetesi de dönemin kapatılan gazeteleri arasında yer almıştı. Ayrıca Mevlanzâde Rıfat'ın on yıl sürgüne gönderilmesi kararı alınmıştı. Aynı gazetenin yurt dışında basılıp yurda getirilmesine ilişkin önlemler de alınmıştır (Ayaz vd. 2015: 112). 
Yönetimi iyice ele geçiren İttihat ve Terakki Cemiyeti otoriter bir yönetim tarzı sergilemeye başladı. Memurlardan kendisine karşı gelenleri tasfiye etti. $\mathrm{Bu}$ arada partizanlık furyası baş gösterdi. Ordu içerisinde subayların birbirini vatan haini ilan etmeye başlaması üzerine Cemiyetten kopmalar yaşandı (Ayaz vd. 2015: 108).

Hüseyin Hilmi Paşa'nın kurduğu yeni hükümet isyanın bastırılmasına yardım edenleri ödüllendirmiştir. Yıldız Sarayı'nda bulunan dokümanlara ve Abdülhamit'in servetine ordu tarafından el konuldu ve 330 sandık jurnal Mahmut Şevket Paşa'nın emriyle yaktırıldı. Avcı Taburları ve Hassa Taburları suçlu bulunarak yol inşaatında çalıştırılmak üzere Rumeli’ye gönderildi. Hatta Avcı Taburları'nda akrabalarını ziyaret edenler dahi Harbiye Nezareti tarafından tutuklanmıştır. Bunun dışında müebbet kürek çekme cezasına çarptırılanlar da Bodrum'a gönderilmişlerdir.

$\mathrm{Bu}$ süreçle ilgili genel değerlendirme yapmak gerekirse Pertev Tevfik Bey'in ifadeleri burada önemli olabilir. Ona göre İttihat ve Terakki, kendisini eleştirmeyi meşrutiyete karşıtlık olarak değerlendirmekteydi. Ayrıca Cemiyetin eleştirilere karşı tahammülsüz bir tavır içerisine girdiğini, muhaliflere gece yarıları baskınlar düzenlendiğini, usulsüz sorgulamalar yapılarak halkı soğutan ve uzaklaştıran bir tavır sergilendiğini, meşrutiyetin koruması gereken can ve mal güvenliğinin hiçe sayıldığını, muhalifleri gizli bir cemiyetin üyesi olmakla itham edilip Divan-1 Harb'e sevk edildiğini ifade etmektedir. Dolayısıyla İttihat ve Terakki Cemiyeti'nin meşrutiyet ilkelerinden uzaklaşarak muhalefeti sindirme gayretine düştüğünü, usulsüz tutuklama ve baskıcı tutumuyla da despot bir tavır içerisine girdiğini belirtmektedir.

\section{Sonuç}

Siyasal iktidar-muhalefet ilişkileri demokrasi tarihimiz açısından üzerinde durulması gereken bir meseledir. Türk siyasal kültüründe siyasal iktidarın muhalefete karşı oldukça tahammülsüz olduğunu, muhalefet kavramına yönelik son derece hasmane bir tutum takındığını görmekteyiz. Muhalefete karşı tahammülsüzlüğün görüntüsü suçlamalarda görülmektedir. "Bölücülük ya da vatana ihanet" olarak itham edilen suçlamaların amacı muhalefeti tasfiye etmek amacıyla ileri sürülmüş bilinçli iddialardır. Amaç mümkünse muhalefeti tamamen ortadan kaldırmaktır. Başka bir ifadeyle siyasal iktidar sahiplerinin firsat buldukça ya da yakaladıkları ilk firsatta muhalefeti sindirmeye, tasfiye etmeye ve yok etmeye çalıştıklarını görmekteyiz. Türk siyasal yaşamında siyasal iktidarların bu sert ve katı tutumu süreklilik arz etmektedir. Ciddi anlamda siyasal muhalefetin ilk defa belirmeye başladığı Osmanlı Devleti’nin son dönemlerinde, II. Meşrutiyet döneminde, İttihat ve Terakki'nin siyasal alanda belirmeye başlamasından itibaren, 2000'li yıllara kadar, siyasal iktidarın tahammülsüzlük içeren bu tutumunun süreklilik taşıdığını görmekteyiz.

Kısaca II. Meşrutiyetten itibaren Türk siyasal kültüründe siyasal iktidarlar hiçbir şekilde muhalefete tahammül edememiştir/edememektedir. Bunun için hukuki alan içerisinde kalıp kalmamak 
hiç önem taşımamıştır. Siyasal iktidarların bu tasfiye sürecinde sık sık legal sınırların dışına çıktığını ve illegal yöntemlerle muhalefet tasfiye ettiklerine şahit olunmuştur.

II. Meşrutiyetten Türkiye Cumhuriyeti’ne miras olarak devredilen siyasal kültür aynen devam ettirilmiş, muhalif olmak, muhalif kanatta yer almak, insan yaşamı için önemli riskleri de bünyesinde barındırmıştır. Muhalif olanlar bölücülük, vatana ihanet, siyasal rejimi tehdit etmek ve yıkmak için örgüt kurmak gibi sert ithamlarla suçlanmışlar; sürekli gözaltında tutma, takip etme gibi tedhiş ve yıldırma siyasetine maruz kalmışlar; hatta bazen suikastlara kurban gitmişlerdir. Bunları yapanlara da değişik isimler kullanılmakla beraber genelde komitacı denmiştir. Öyle ya da böyle nerede bir siyasal cinayet/suikast gerçekleşmişse bu durum komitacılıkla bir tutulmuş ve cinayetin faillerine de komitacı denmiştir. İşte bu komitacı geleneğin ilk suikastı/cinayeti de Hasan Fehmi Bey suikastıdır.

Hasan Fehmi Bey muhalefet adına sadece bir bireydir ve demokrasiye geçiş sürecinde basın adına bedel ödemiştir. Oysa ki demokrasiye geçişin bedeli sadece gazeteciler tarafından değil tüm milletçe ödenmektedir. Türk milletinin tarih boyunca bünyesinde var olan özgürlük ve adalet anlayış1 bu çizgiden çıkanlar için bir itiraz sebebi olagelmiştir. Bu durumda ya Türk milletinin bu duygularını yitirmesi ya da demokrasi ile bu isteklerin verilmesi gerekmektedir. Aksi halde bu tür bir antidemokratiklik hem ülke içinde kaoslara hem de yurt dışında imajımızın sarsılıp dış müdahalelerin yaşanmasına sebep olmaktadır. Türk milleti yöneticileri ilk yazılı kaynaklarımız olarak kabul edilen Orhun Abideleri'nde olduğu üzere her zaman milletine hesap veregelmiştir. İslam'ın kabulü ile daha da güçlenen bu duygu var olan Türk siyasal kültüründe büyüyerek devam etmiştir.

Sonuçta, meşrutiyetle birlikte Türk siyasal yaşamı ilk kez demokratik bir sistemle yani meşrutiyetle tanışmış, demokrasinin yerleşme ve olgunlaşma sürecine tanıklık etmiştir. Siyasal iktidarı elde etmek için çırpınan her türlü kesim ve grup, var olan siyasal iktidardan demokrasiyi tesis edemediği ve özgürlükleri tanımadığı için şikâyet etmiş, fakat iktidar koltuğuna oturduğunda da şikâyet ettiği ve yakındığı demokratik olmayan her türlü tutum ve davranışı daha fazlasıyla yürüterek halka zulmetmiştir. Bunun en büyük sebebi siyasal iktidar mücadelesindeki bireylerin demokrasiyi kendi özel ve sınıfsal ihtiyaçlarını karşılayan bir mekanizma olarak görüp bir oyun hamuru gibi ellerine alıp şekil vermelerinden ileri gelmektedir. Hâlbuki demokrasi siyasal iktidarın değil halkın memnuniyetini sağlamanın bir aracıdır ve bu görmezden gelinmiştir. Bunun yaşanmasının sebebi meşrutiyet döneminde seçilmişlerin belli bir eğitimden geçme ve demokrasiyi anlama ve uygulama gibi kabiliyetlerinin yetersiz olmasından, ahlaki olarak bir zafiyet taşımalarından ve tam anlamıyla demokrasiye inanmamalarından kaynaklanmaktadır. Nihayetinde bu durum demokrasinin ve demokratikleşme mücadelesinin beklenenden uzun sürmesine sebebiyet vermiştir. 


\section{Kaynakça}

Ahmad, Feroz (2016) İttihat ve Terakki 1908-1914, Kaynak Yayınları, İstanbul.

Ahmetoğlu, Selim (2011) “31 Mart İsyanı’nın Trabzon'daki Yankıları”, Türkiyat Mecmuası, C.21, Güz, ss. 117.

Akbal, İsmail (2004) 1919-1923 Yllları Arasinda Muhalif Kimliğiyle Trabzon, Ankara Üniversitesi Sosyal Bilimler Enstitüsü Kamu Yönetimi ve Siyaset Bilimi Ana Bilim Dalı, Doktora Tezi, Ankara.

Akbal, İsmail ve Mehmet AKINCI (2013) "Türkiye'de Siyasal İktidar-Muhalefet İlişskilerinde Muhalefete Tahammülsüzlügün Aynası: Basın ve Tasfiyeler”, Uluslararası Yönetim İktisat ve İ̧sletme Dergisi, C.9, S. 18 , ss. 31-50.

Akşin, Sina (2014) Jön Türkler ve İttihat ve Terakki, İmge Kitabevi, 7. Baskı, Ankara.

Ayaz, Erhan, Muammer ERDEM ve Yunus Kuloğlu (2015) "II. Meşrutiyet Döneminde Bir Faili Meçhul: Hasan Fehmi Bey", Electronic Journal of Vocational Colleges, May/Mayıs, ss. 107-117.

Aysal, Necdet (2006) "Örgütlenmeden Eyleme Geçiş: 31 Mart Olayı”, Ankara Üniversitesi Türk İnkllâp Tarihi Enstitüsü Atatürk Yolu Dergisi, S.37-38, Mayıs-Kasım, ss. 15-53.

Borak, Sadi (1979) “Türkiye'de Siyasi Suikastlar-I”, Milliyet, 17.02.1979, s. 5.

Borak, Sadi (1979) “Türkiye'de Siyasi Suikastlar-II”, Milliyet, 18.02.1979, s. 6.

Çavdar, Necati (2011) "Siyasi Denge Unsuru Olarak 31 Mart Vakası'nda Ahmet Tevfik Paşa Hükümeti”, History Studies Uluslararast Tarih Dergisi, Volume 3/1, ss. 69-82.

Çaycı, Muhammet Emin (2009) Osmanlı Basınında 31 Mart Olayl, Dokuz Eylül Üniversitesi Atatürk İlkeleri ve İnkılap Tarihi Enstitüsü, Yüksek Lisans Tezi, İzmir.

Çopur, İzzettin (1982) 31 Mart Ayaklanması, Atase Yayınları, Ankara.

Felek, Burhan (1963) “Siyasi Olaylar-2”, Milliyet, 26.07.1963, s. 2.

Felek, Burhan (1980) 31 Mart Vakası, Taha Toros Arşivi, İstanbul.

Hasan Amca (2013) Yarıda Kalan İhtilal, Alfa Basın Dağıtım, İstanbul.

Kabaçalı, Alpay (1993) Türkiye'de Siyasal Cinayetler, Altın Kitaplar Yayınları, İstanbul.

Kerimoğlu, Hasan Taner (2007) "İkinci Meşrutiyetin İlk Yıllarında Sürgün ve Firariler Sorunu ve Fedakâran-1 Millet Cemiyeti”, Ege Üniversitesi Türk Dünyası Araştırmaları Dergisi, C.7/2, ss. 133-149.

Kerimoğlu, Hasan Taner (2009) "II. Meşrutiyet Döneminde Genel Haklar Savunusu Yapan Bir Gazete: Hukuk-1 Umumiye", CTTAD, C.VIII/18-19, Bahar-Güz, ss. 21-38.

Kurşun, Zekeriya (2000) “irtica'nın Arkasindakiler”, Tarih ve Düşünce, Nisan.

Metin, Erhan (2016) "II. Meşrutiyet Dönemi Siyasi Olayları", http://websitem.karatekin.edu.tr/ user_files/dosyalar_(Erişim Tarihi: 12.11.2016).

Mevlanzâde Rıfat (2010) 31 Mart-Bir İhtilalin Hikayesi, Pınar Yayınları, İstanbul. Milliyet, 21.1.1955, s. 7.

Savaş, Mevhibe (1998) İkinci Meşrutiyet Döneminde İttihat ve Terakki ve Basın, Gazi Ün. Fen-Ed. Fakültesi Yayınları, Ankara.

Tabak, Serap (2005) “İzmir’de II. Meşrutiyet Dönemi’nin Başlarında İç Siyaset”, Tarih İncelemeleri Dergisi, C.20, S.2, Aralık, ss. 113-132.

Tunaya, Tarık Zafer (1988) Türkiye'de Siyasal Partiler, C.1, Hürriyet Vakfı Yayınları, İstanbul.

Turgut, Nükhet (1984) Siyasal Muhalefet, Birey ve Toplum Yayınları, Ankara.

Türkçe Sözlük (1995) Türk Dil Kurumu Yayınları, C.II, Ankara.

Yalçın, Hüseyin Cahit (2000) Siyasal Anılar, Tíş Yayınları, İstanbul. 